
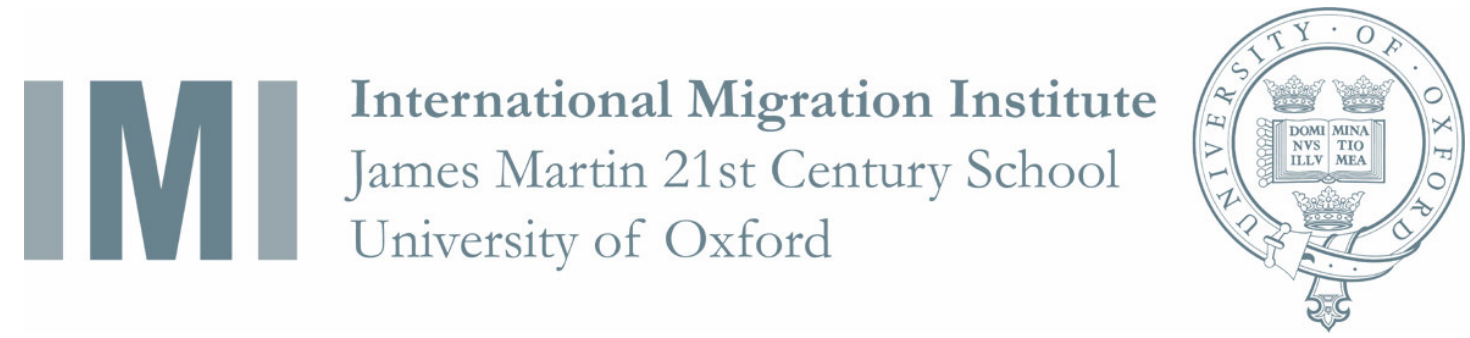

Working papers

Year 2007

Paper 8

\title{
Keeping Them in Their Place: the ambivalent relationship between development and migration in Africa
}

Oliver Bakewell

The IMI does not have a view as an Institute and does not aim to present one. The views expressed in this document are only those of its independent author. 


\title{
Keeping Them in Their Place: the ambivalent relationship between development and migration in Africa
}

\author{
Oliver Bakewell
}

\begin{abstract}
Migration has moved to the centre stage of development policy after decades of waiting in the wings. For most of the last sixty years, migration has been portrayed in development circles in largely negative terms and identified as one of the problems that development aims to address in Africa. Suddenly in the last five years, the potential positive role of migration in the development process has been recognised - in particular the contribution of migrants through remittances, skills transfers, and the development of transnational networks. A virtuous circle has been identified, whereby migration supports economic growth and development and this in turn reduces the pressure for further migration. Researchers and policy makers are now hunting for conditions which make for a 'win-win-win' situation where migration is beneficial for countries of origin, countries of settlement and the migrants themselves. Despite this apparent change in attitudes to migration, the vast majority of development agencies hold on to a sedentary model of development; they aim to enable people to achieve a better quality of life at 'home'; within such models continued migration is an indicator of failure. This sedentary bias is a reflection of the roots of the 'development project' in Africa in the colonial administrations of twentieth century. Today, many of the new initiatives on migration and development have the implicit objective of reducing the flow of international migration, especially to the industrialised world. However, for many people in Africa increased opportunities for international migration (within and outside the continent) are an essential ingredient for their future well-being. Migration has always been a strategy used by people to try to improve their quality of life, and a development industry that fails to recognise this will severely limit its impact on poverty reduction.
\end{abstract}

Key words: rural-urban migration, international migration, development, NGOs, Africa, colonialism, development policy, diaspora.

\section{Author:}

Oliver Bakewell is a Research Officer at the International Migration Institute, University of Oxford. Email - oliver.bakewell@qeh.ox.ac.uk 


\section{INTRODUCTION ${ }^{1}$}

In the last five years, migration has arisen to the top of the development agenda after being of marginal interest to development studies and development policy and practice for many years. Today, the potential contribution of migration to development is being trumpeted by states - especially industrialised states - multilateral organisations, non-governmental organisations (NGOs or non-profits), wider civil society and academics. The old rhetoric of migrants' remittances being used for 'conspicuous consumption' is being supplanted by an analysis which highlights both the scale and the economic multiplier effects of the money sent home. Migrants who, having left their country, were once seen as embodying the problem of the 'brain drain' are now courted as agents of development.

As the complex relationship between migration and development has moved to the centre stage of current development debates and policy, it has generated a huge volume of new research, policy initiatives and interventions. Its importance to policy makers was illustrated by the High Level Dialogue on Migration and Development convened by the United Nations in September 2006, to be followed by the Global Forum on Migration and Development in July 2007. However, among the growing wealth of materials, some of which I will discuss below, it is remarkable how rarely any attempt to problematise, or even define, the term 'development' is included. In this paper, I focus on the often neglected question of what is meant by development in this context. Where does this concept come from, what are its roots and how does it relate to migration?

Few would contest that migration affects the process of development and also development affects migration patterns. However, when it comes to the nature of the relationship between migration and development, the only commonly accepted ground is that it is extremely complex. While this complexity is widely acknowledged, for the most part migration scholars who engage in development issues have focused on how far migration either contributes to or hinders the achievement of the 'target' or 'goal' of development (and development is commonly seen in such a teleological light), drawing on notions of development accepted within development studies. This results in studies which show when and how migration has

\footnotetext{
${ }^{1}$ This paper has been developed through presentations at the International Metropolis Conference, Lisbon, October 2006, the European Conference on African Studies, Leiden, July 2007, Institute for African Development, Cornell University, the Development Management Network, George Washington University, the African Studies Centre, University of Oxford and the Centre for Development Studies, University of Bath. I am grateful to the participants and organisers of these events. I am also grateful to Stephen Castles and Hein de Haas for their valuable comments on earlier drafts of the paper.
} 
a positive or negative outcome for development. These have been the basis for many of the emerging policies on migration and development.

However, my argument in this paper is that we have to consider not only how migration contributes to hitting (or missing) the target, but also how it actually changes the nature of that target. I will argue that the very notion of development, as understood and applied by the 'mainstream' of development 'professionals' (both practitioners and academics), has a sedentary bias. As a result, in many circles, migration and development make uncomfortable bedfellows, despite the newfound widespread enthusiasm for their cohabitation.

In the next section, I start by reflecting on the roots of the 'development project' in Africa and show how it has long been associated with the colonial concern about the control of mobility. I then show how until recently both internal and international migration has consistently been framed by development actors as a problem to be addressed, with the expectation that development progress will reduce migration pressures. The following section describes how migration and development has moved back to the centre stage of research and policy. However, this has not been accompanied by a significant change in mainstream development actors' ambivalent views of migration. In the search for 'win-win-win' scenarios that maximise the benefits of migration for countries of origin, countries of destination and migrants themselves, there is an underlying assumption that development is about enabling people to stay at 'home'. The final section argues that analysing the interaction between migration and development raises fundamental questions about the nature of the good life, the focus on the nation state and the inherent paternalism found in the current notions of development. In conclusion, I argue that development needs to be reconceptualised for a mobile world.

Given that I am objecting to the uncritical use of the term of development by others, it is important for me to start by outlining the perspectives I bring to this paper, before moving on to the main argument. Over the last fifty years, development studies has been through various schools of thought including modernisation, dependency and world systems theories, which gave radically different analyses of the causes of (under)development and hence potential solutions. What these different schools have tended to share is a 'modernist ideology' (Simon 2006: 11) which holds to a fundamental belief in the concept of progress. In contrast, 'postdevelopment' authors, such as Escobar (1995a; 1995b) call into question the whole idea of development, as reflected in current institutions and procedures, as an ongoing exercise in 
Northern imperialism. The post-development school has been criticised for failing to offer any substantive responses to the real struggle for survival facing people in many parts of the 'developing' world (Schuurman 2000). Others have attempted to build bridges between the different perspectives (Brigg 2002; Simon 2006). These important debates are ongoing but so far they have had limited impact on the practice of development, which has, not surprisingly, remained rooted in a belief in progress. Hence, for the purpose of this paper, I will draw on these classical notions of 'development as progress' that guide practice.

The extent to which development should be considered to be the result of specialist 'development' programmes or to be embedded in broader processes of historical change depends on ones perspective (Kothari 2005b: 4). In this paper, I am starting from the perspective of mainstream 'interventionist' development studies. I am focusing on the concept of development as both a vision for progressive change or idea of a desirable future state, and a concern about how to bring about such change. Many development actors and much of development studies tend to focus on the latter, which lends itself to debates about technical approaches and analytical 'tools', development management, and policy formulation (Kothari 2005b: 4-6).

However, such concerns cannot be separated from profound and unresolved (or irresolvable) debates about the underlying changes which are desired. Development will always remain a contested notion and perhaps the most pressing question is whose idea of development counts. Narrow views of economic development, assessed principally by economic indicators, have been supplemented by broader views, which encompass a much wider range of measures, including social, political and cultural indicators of positive change. These are well established in the Human Development Index but are being further refined by attempts to consider improvements in the well-being of people, which take into account subjective changes that are celebrated by people and give them a greater sense of freedom, autonomy, and control over their lives (drawing on Sen 1999; White and Pettit 2004 among many others). ${ }^{2}$ From these perspectives, development cannot be assessed by recourse only to standardised indicators; it should entail changes that are seen as desirable to the people those living in poverty and denied of their human rights.

\footnotetext{
${ }^{2}$ For example, see the work of the ESRC Research Group on Well-Being in Developing Countries at Bath University (www.welldev.org.uk) and the Oxford Poverty \& Human Development Initiative (www.ophi.org.uk).
} 
In this paper, I am focusing on development aid as a distinct area of practice, conducted by development organisations staffed by development professionals, and often informed by academics engaged in development studies. This includes line ministries in developing countries, development departments in donor governments (e.g. USAID, DFID, Sida), multilateral organisations (e.g. the World Bank, UNDP, African Development Bank) and civil society organisations, in particular national and international development nongovernmental organisations (NGOs).

It is clear that significance of development aid as a driver of change within developing countries is often outweighed by many other factors such as political reform, new private sectors investments and technological advances. For example, in many parts of the world the advance of mobile telephones has revolutionised communications even in the poorest areas. While this has made a major contribution to development, it has been largely driven by private enterprise rather than as the result of 'development' initiatives. Similarly, the establishment of a new factory is likely to contribute to development but that will not be its primary aim (and experience has shown too often that enterprises established primarily as 'development' activities tend to have a very low success rate).

Although the importance of development aid may often be overstated, especially by development actors, it constitutes a significant portion of the national economy in many countries in the poorest regions of the world. In particular in Africa, which is the focus of this paper, official development aid represents over a quarter of GDP in 11 of the 53 countries across the continent ${ }^{3}$. Sub-Saharan Africa is the only region of the world where official development assistance still outweighs remittances and foreign direct investment (see Figure 1 below).

As a result, Africa is the continent where development discourse and practice appears to have had the strongest impact on at least the external views of the continent, if not the actual reality faced by its peoples. While this must in part be a reflection of the sustained and deep poverty experienced in many countries across Africa, the colonial legacy remains deeply embedded in policy, media representation and scholarship.

'Despite all the talk of 'empowerment', 'partnership' and 'participation', development is still something that is defined and enunciated by the 'first world'. Just

\footnotetext{
${ }^{3}$ Based on 2004 figures from World Bank data (http://devdata.worldbank.org/data-query/)
} 
as in colonial times, the frameworks and strategies of development are authored outside of the country concerned, grounded in foreign (especially neo-liberal) ideologies and backed up by the long-arm of debt conditionality.' (Mercer et al. 2003: 423).

In the next section, I focus on these European roots of the concept of development and how they became embedded in colonial practice, in particular with respect to migration, and were then carried into the forms of development as we see it practiced across Africa today.

Figure 1: Foreign direct investment, remittances and official development aid (2005)

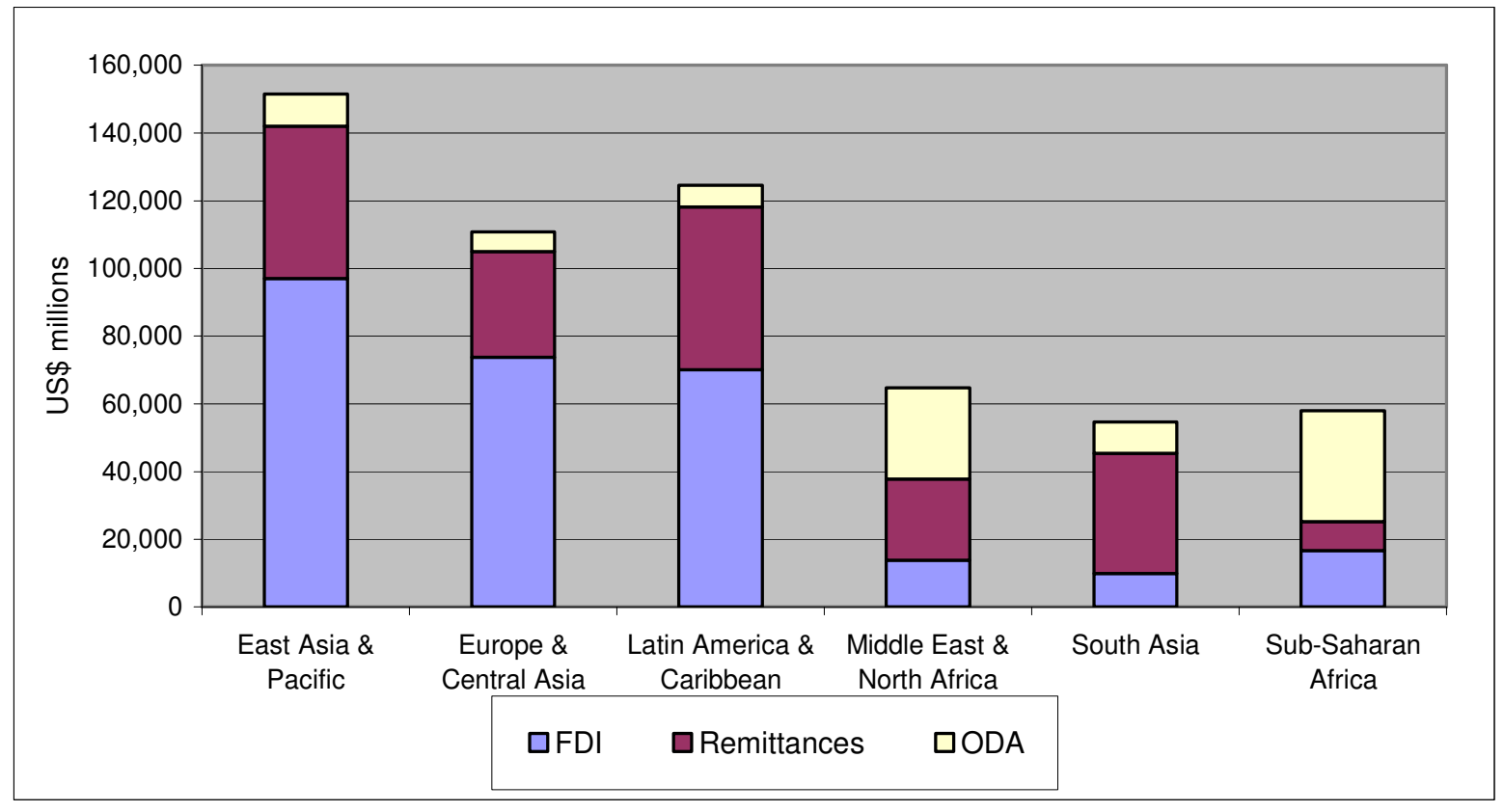

Source: World Bank: http://devdata.worldbank.org/data-query/

\section{MOBILITY AND THE ROOTS OF DEVELOPMENT}

The origins of the notion of development as a distinct arena of social practice are commonly traced back to the middle of the $20^{\text {th }}$ century with the establishment of the Bretton Woods institutions and a concern to ensure that newly independent states moved firmly into the capitalist global order. However, while this period may represent the beginning of the institutionalisation of development practice, and development studies (Harriss 2005; Watts 1995), the concept has much deeper roots. Cowen and Shenton (1995) argue that the notion of 'development' emerged as an attempt to address the perceived chaos caused by the rapid technological, social and economic change of the industrial revolution in the $18^{\text {th }}$ century. 
'The modern idea of development is necessarily Eurocentric because it was in Europe that development was first meant to create order out of the social disorder of rapid urbanization, poverty and unemployment' (Cowen and Shenton 1995: 29)

This new sense of ongoing progress of 'well-developed human beings' towards a stable end state contrasted with the prevailing classical ideas of endless cycles of growth, maturing and decay. The philosopher John Stuart Mill argued that such development could only take place in societies based on tolerance and rationality rather than those hidebound by primitive customs. Where such conditions did not prevail, progress would only be achieved if it was introduced from outside by more advanced societies. Such arguments directly underpinned the colonial doctrine of 'trusteeship' which aimed 'to create conditions under which education, choice, individuality - in a word development - might occur' (Cowen and Shenton 1995: 41). Although these roots in colonial administration are seldom acknowledged by those engaged in development today, they were clearly carried across into the post-colonial ideas of development as a 'professional' practice. Many of the early development practitioners had transferred from colonial service and there were close parallels between ideas of trusteeship and the theories of modernisation which dominated development studies in the 1960s (Kothari 2005a).

While the theories and practice of development appear to have moved away from such blatant hangovers from the colonial past, many of these roots remain in place. For example, Mercer et al. argue that the UK's promotion of the New Partnership for Africa's Development (NEPAD) and DFID's White Papers, with the concern for giving African states appropriate tools for bringing about development and progress, exhibit 'an enduring trusteeship towards the continent' (Mercer et al. 2003: 420). Thus, there are fundamental aspects of the 'development project' which remained unchanged: in particular, its ongoing ambivalence, or at times even hostility and fear, towards human mobility that is outside the control of states.

From the earliest days of widespread European incursions into Africa, a major concern was to gain control over the movement of people in order to direct it towards the aims of the invaders. This took its most brutal form in the transatlantic slave trade as the export of the people's labour power was their primary interest. As the Europeans established their colonies and directed their attention to the massive exploitation of the mineral wealth and natural resources that lay within the continent, they faced the challenge how to engage the labour of Africans in the colonial endeavour. 
In some cases this was achieved by forced labour, little removed from slavery. For example, the use of forced labour by the Portuguese on plantations until the middle of the 20th century maintained the effective practice of internal slavery for a century after the end of international trading (Henderson 1978). Others adopted more indirect mechanisms to force Africans into the cash economy so they had to undertake wage labour in the mines of southern Africa, the rubber, cocoa, coffee and tea plantations of east, central and western Africa, and in the colonial administration, the armies and police forces across the whole continent. The introduction of hut and poll taxes, the expropriation of the best land for settler agriculture, and the provision of services for wage labourers were all policies that served to ensure Africans had to offer their labour to earn cash.

Thus the functioning (and profitability) of the colonial state required that people move to work. It needed large concentrations of populations to come together to provide the labour for mines, plantations and the colonial administration. At the same time, with this mass movement of people there was great concern to ensure that such people did not settle permanently in these new centres (Rakodi 1997b). Labourers were welcome but they should retain their link with their homelands and ideally, when they finished their contract or came to retirement, they would return 'home' to make way for new labourers ${ }^{4}$.

While the colonial authorities established a labour system based on the continuous (circular) migration of Africans, they were also keen to encourage them to maintain their 'traditional' way of life in the villages; to preserve the 'homes' to which labour migrants could return. In many areas, this was assumed to be a largely sedentary existence based around stable villages in fixed locations populated by particular (static) 'tribes'. The colonial systems for the collection of taxes, the imposition of colonial law, and the provision of government services all relied on a good understanding of who was where. Mobility confused the picture.

'Colonial rulers were dismayed at the high mobility exhibited by villagers in Northern Province [of Zambia] and could not understand why people did not stay put in "proper villages" They were sure that such behaviour was not "traditional" but the result of recent pathology brought on by industrial development and the "migrant labour system." Small temporary villages, with people moving about in an undisciplined manner between them, they felt sure, were a sign of the "breakdown" of

\footnotetext{
${ }^{4}$ They can be seen as precursors to the guestworker systems established in Europe in the second half of the $20^{\text {th }}$ century (Castles 2006).
} 
traditional institutions, a breakdown that government policy would have to check if "detribalization" was not to be avoided (Ferguson 1999: 39).

Thus, while the colonial states could never be sustained without circular migration, permanent migration was widely seen as presenting major problems for both the sending and receiving areas. Migration represented a core research theme running through many of the classic studies produced by colonial anthropologists; for example, from Zambia alone, there were studies on the Bemba (Richards 1939), Mambwe (Watson 1958) and the Gwembe Tonga people (Colson 1971; Van Velsen 1960). Although later studies critiqued their predecessors' lack of any gendered analysis of migration and their assumptions of 'tribal' identities with unchanging traditions (Moore and Vaughan 1994; Pottier 1988), such detailed anthropological studies, which were also produced in many other countries, offered extremely rich and complex pictures of the relationship between migration and change in rural and urban societies.

However, their fine detail was lost in the broad brush portrayal taken up within the emerging field of development, which focused on the potential negative impact of out-migration on rural areas with the fall in agricultural production due to the reduction in male labour (though as Moore 1990 points out, this was paradoxical as the contribution of women's labour to agriculture was well known). Although the practice of sending remittances from urban areas back to the village was widespread, these remittances were often seen to be used for conspicuous consumption rather than invested in productive enterprises (Birks and Sinclair 1980 cited in Keely and Tran 1989: 502). Moreover, they were thought to increase inequality within rural communities (Lipton 1980).

The picture was little better in the urban areas, where unplanned in-migration was seen as overwhelming the embryonic urban structures (Rakodi 1997b). For colonial states, the growing urban population of poor and underemployed workers presented major social, economic, and even moral challenges. In particular, the gender imbalance encouraged by the (predominantly male) labour migration system not only broke up families in the rural areas but created the perfect environment for the growth of prostitution and the exploitation of women in the growing cities. Thus planners faced the dilemma of allowing labourers to move with their families, effectively creating permanent settlements, or trying to impose stringent controls on settlement and dealing with the resulting social tensions. 
As African states gained their independence in the second half of the twentieth century, the control of urban growth remained an urgent policy concern. In South Africa, the apartheid state implemented its racist pass laws in order to control permanent urban settlement and try to ensure the black African population remained in their 'homelands'. In other parts of the continent, while many of the newly independent states showed an urban bias in policies of industrialisation and modernisation focused on the cities (Rakodi 1997a), the focus of many aid programmes was on the development of rural areas, which was seen as essential to enable people to stay in the villages rather than try their luck in the ever growing cities.

It is therefore not surprising that the concerns about issues of development aid and poverty which took root in the 1960s and 70s focused on the rural areas. There were massive government investments in rural development programmes, agricultural extension, and rural infrastructure (such as roads, water supply, health facilities and schools). This was not only concerned merely with improving the quality of existing village life. There were also many attempts at transforming patterns of rural settlement to create new 'villages' which were better suited to modern agricultural production, inspired by socialist models of collectivisation.

This is not to suggest that the control of rural-urban migration was the only reason for such rural development policies. Conditions in many rural areas were appalling and increasing agricultural production, both to ensure the food supply to the growing cities and for export crops, was a critical issue. However, as Black observes, policies such as Tanzania's villagisation 'arguably reinforced a mindset amongst policy makers that development was best promoted through interventions in rural areas that would reduce the need for migration.' (2004: 27). Deshingkar and Grimm put it more strongly,

'Implicit in many agricultural or rural development policies in Africa is the aim of controlling population movements.' (2005: 46)

More recent policies of decentralisation acknowledged the need for rural people to have option of moving to smaller towns but still discouraged settlement in the capital cities (Black et al. 2004; Rhoda 1983: 60).

The generations of large-scale government led rural development initiatives supported by donors, such as Area Development Programmes and Integrated Rural Development Programmes (Cohen 1987), left a legacy of office compounds, broken down vehicles and 
reports in district centres across Africa, but did not bring the desired change in the rural economies or a reduction in rural emigration. As donors became disillusioned with the failure of development led by developing states, citing problems of corruption and inefficiency and the ideological shift away from the state in the 1980s, the baton was passed on to NGOs as major driving forces in development activity. For many years, they maintained the overall emphasis on addressing rural poverty and it is only in the last decade that urban poverty has come more strongly onto their agenda (Sahley and Pratt 2003).

Throughout these development initiatives, whether they arise from states or NGOs, there has been an underlying sedentary bias. There is an expectation that people want to remain in their place.

A common belief is that improved conditions in rural areas will reduce rural-urban migration and consequently reduce the growth of urban poverty. Based on this belief, many rural development interventions have been justified partially on the grounds that they will reduce urban migration. (Rhoda 1983: 35)

What is remarkable about these attempts to control rural-urban migration through rural development and controls in urban areas is that they have been largely futile. Urbanisation across the continent has increased regardless of attempts to slow it (Rakodi 1997c).

Development in areas of origin usually goes hand-in-hand with migration, and expectations that rural development will decrease out-migration may be unjustified (though it is likely to change the conditions of migration and composition of migrants). (de Haan 1999: 20)

Far from being an indicator of successful development, reverses in rural-urban migration have been associated with economic decline and the collapse of employment opportunities in urban areas (Potts 1997; Simon 1997; Skeldon 1997a). For example, the contraction of the mining sector in Zambia and the widespread retrenchment of staff in the 1990s triggered a marked exodus of people from the Copperbelt back to the rural areas. However, this reduction in the net rural-urban migration in the country has not meant the end of movement. The return of redundant workers from the mines and related industries has been partially offset by the continued movement of young people moving from rural areas to the Copperbelt (Ferguson 1999). 


\section{DEVELOPMENT AND MIGRATION THEORY}

Therefore, from its earliest roots, development practice has commonly seen a reduction in migration as either an (implicit or explicit) aim of intervention or an indicator of a programme's success. Not surprisingly, this view has been consistently echoed in the emerging academic field of development studies, where the literature tends to frame migration as problem. It is frequently portrayed it as a response to crisis rather a 'normal' part of people's lives (de Haan 1999: 2), especially in Africa.

Whereas standard economic theories emphasise the advantages of a free flow of labour, development studies tends to look at migration with a great deal of reservation. It is usually agreed - often without the historical data to back this up that population movements are happening at an unprecedented scale. This goes for much of the literature on urbanisation, and also with respect to international migrants. (de Haan 1999: 2)

While the literature has acknowledged the complexities of the relationship between migration and development, the general tenor of the debate has portrayed that relationship as negative. Moreover, until very recently, the issue of migration was not regarded as central to development; for example, in universities, migration, especially international migration, has often tended to be a sideline in development studies and until recently, it has rarely been included as a core topic in university teaching on development. ${ }^{5}$

The expectations of slowing or reversing rural-urban migration by improving conditions in the rural areas were consistent with the wide range of migration theories to explain peoples' movement put forward in the 1970 s and $1980 \mathrm{~s}^{6}$. Neo-classical theories, such as that put forward by Harris and Todaro (1970) start from the premise that the prime agent in migration is the individual migrant, who makes a rational decision to migrate on the basis of some evaluation of its utility, especially related to expected wage differentials. In contrast structuralist theories see the individual migrant as responding to the social structures in which they find themselves rather than as the prime agents. Within these models, migration is a passive response to the economic, social and political environment which is beyond the individual migrant's control (Amin 1974). Systems theories introduce feedback between

\footnotetext{
${ }^{5}$ For example, the Development Studies Association 'Guide to Development Studies Courses in UK and Ireland' list 54 institutions with development courses of which only four list courses covering migration issues (http://www.devstud.org.uk/courseguide/ accessed $18^{\text {th }}$ April 2007).

${ }^{6}$ For a detailed survey of migration theories see (Massey et al. 1998)
} 
migrants, their families and the broader context in which they move. The earliest proponent of a systems approach, Mabogunje described a system as a 'complex of interacting elements, together with their attributes and relationships' (1970: 3). The major elements in the migration system are the potential migrant, rural and urban institutions and socio-economic relationships, in an economic, governmental, technological and social environment.

During the 1980s and 1990s, there have been attempts to bridge the gap between these different approaches, most notably in the new economics of labour migration (Stark and Bloom 1985), which addressed the fundamental weakness of neo-classical approaches: their neglect of institutions. It both deepened the neo-classical analysis to incorporate more structural factors such as government policies, social capital and relative deprivation (De Jong and Gardner 1981; Stark 1984) and broadened it to look beyond the individual to the household as the unit of analysis (Achanfuo-Yeboah 1993; Daveri and Faini 1995; Rosenzweig and Stark 1989).

Within these theories, the basic assumptions and analysis of the processes driving migration are very different. However, they all feature, at least implicitly, the level of 'development' as a crucial variable. Migration is seen to be caused by imbalances either in wages, opportunities, social structures, levels of capitalist penetration, and so forth. Therefore, they tend to suggest that reducing the imbalance will eventually reduce migration. While investing in development may initially trigger increased out-migration, as increased incomes unlocks people's latent desire to migrate, if the economy continues to grow, the flow is expected to reverse after this temporary 'migration hump' (Martin and Taylor 1996).

The discussion so far has largely focused on internal migration but when we turn to consider the debates around international migration and development, the parallels with rural-urban migration are striking. International migration is widely seen to be driven by relative poverty and the lack of opportunity in developing countries (push factors) and a growing demand for labour industrialised states (pull factors). In the same way that labour migration was seen as reducing productivity in rural areas, the disproportionate presence of highly educated and skilled people among migrants from Africa has provoked a massive concern about the impact of this 'brain drain' on their countries of origin.

While migrants' remittances provided large flows of income to some developing countries, much has been made of their being used for consumption (in particular the purchase of 
imported manufactured goods) rather than investment, and their development potential has been regarded as quite limited. Moreover, remittances were seen as likely to increase inequality as they flow predominantly to migrants' families, excluding those outside the migrant networks, especially the poorest households (see de Haas 2005: 1274; Taylor 1999: 72). With the exception of major emigration countries of North Africa such as Egypt and Morocco, remittance flows to Africa have been thought to be quite low with limited impact on national economies or potential to contribute to development.

Thus, analogous debates about the costs and benefits of migration have been rehearsed for movements from developing countries (the new 'villages') to industrialised states (the new 'cities'). Until very recently, these debates on international migration have tended towards negative views of migration which are similar to their domestic counterparts.

\section{MIGRATION AND DEVELOPMENT MOVING TO CENTRE STAGE}

As recently as the turn of the century, the subject of migration hardly featured in mainstream development discourse. There is no mention of migration or migrants in the Millennium Development Goals (UNFPA 2005) except with respect to the spread of disease, "The deterioration of health systems, growing resistance to drugs and insecticides, environmental changes and human migration, which have led to an increase in epidemics, all contribute to the worsening global malaria problem" (UN 2001). This is not to argue for the inclusion of migration goals in the MDGs, but rather to observe that it is almost unthinkable that such a document would be produced today with such minimal reference to of migration. ${ }^{7}$ In many African countries, the poverty reduction strategy papers (PRSPs) developed in collaboration with states, donors, the World Bank and civil society that lay out the framework for national development plans, say little about migration and very few refer to it in any of their antipoverty strategies (Black 2004: 11).

In the last five years, the relationship between migration and development has moved to the centre stage and there has been a remarkable and rapid turnaround in views. In 1998, Massey et al. reported an official at the International Labour Office in Geneva as saying 'Migration and development - nobody believes that anymore' (1998: 260). Today, it would be hard to find anyone who would subscribe to such a comment.

\footnotetext{
${ }^{7}$ c.f. The IOM World Migration Report 2005, that calls for migration to be inserted into the MDGs - though it is not clear exactly what it is meant by this (IOM 2005: 266). UNFPA takes a more balanced view (2005: 3-4)
} 
The growing numbers of international migrants does not adequately explain this renewed interest in migration and development. The global numbers of migrants - i.e. people living outside their country of birth for more than one year - has increased from an estimated 155 million in 1990 to 191 million in 2005, but this only represents an increase from 2.9 per cent to nearly 3 per cent of the world's population. There are historical antecedents with massive movements of people around the world - from Europe to the Americas, from India and Southern China to south-east Asia, and from north-east Asia and Russia to Manchuria, Siberia, central Asia and Japan - in the last quarter of the $19^{\text {th }}$ century peaking before the First World War (McKeown 2004).

What has increased dramatically is the diversity of migrants and migrants' destinations. In 1960, 30 countries reported having over half a million migrants; by 2005, this had risen to 64 countries. Despite this, the majority of migrants can be found in a relatively small number of countries. 28 countries host 75 per cent of the world's migrants, among which the US is the largest recipient of international migrants with 38 million in 2005. Moreover, migrants are now concentrated in industrialised states (63\%), a reverse from the 1960s (all figures UN 2005).

Since the 1990, net migration from Africa to wealthier regions has grown but it is important to recall that this represents a very small proportion of the overall level of international migration originating in Africa; the vast majority of African migration remains within the continent (Ratha and Shaw 2007: 6; Sander and Maimbo 2003). IOM's World Migration Report 2005 suggests that Africa is hosting a decreasing percentage of the world's migrants, with 9 per cent of the global stock of international migrants in 2000, down from 12\% in 1970 . This is consistent with a drift of migrants away from the continent (but how far such figures reflect the changing patterns of movement or data availability must be open to question).

These figures, like any migration statistics, must be treated with the utmost caution. This caution gets more important when we get to figures on African migration where estimates and guesses are the rule rather than exception. Most international migration in Africa is over land borders which are crossed with minimal if any formalities. Census data is of poor quality and often does not even have migration questions. The UN estimates of migrant stocks in Africa rely on estimates derived from national statistics, when 19 of the 56 countries in Africa have either no data or just one census providing any information on migrant stock from the 1950s (Zlotnik 2003: 3). As a result, there are major gaps in knowledge about the 
forms and patterns of migration across large parts of Africa and the figures provided must be open to question.

In Europe, the most striking increases are in Italy and Spain which have reported annual immigration from Africa rising over three fold in the former and tenfold in the latter, between 1995 and 2000. However, these headlines hide the fact that migration from Africa appears to be a falling as a percentage of their rising immigration levels. Currently, it is Portugal that is seeing the highest increase in African migration (data from Eurostat). European census data shows that $14 \%$ of the foreign born people living in the EU were from Africa, the second largest group of foreign born from outside the EU (Katseli et al. 2006). In the US, migration from Africa represents a small but growing proportion of the overall migration picture. In 2005, only $3 \%$ of the foreign born population had been born in Africa ${ }^{8}$.

Although the increase in the number of migrants from developing countries may have contributed to the renewed interest in the relationship between migration and development, there were a number of other factors that played a more significant part.

Massey et al. contributed to the turnaround by highlighting the weakness of the theoretical and empirical base for many of the commonly held 'truths' about migration and development.

'For the most of the last two decades, however, theory has been inadequate to the task of identifying and understanding the multiple means by which international migration influences economic development' (Massey et al. 1998: 272).

As a result, they concluded,

'Because neither theory nor data have been up to the task of evaluating migration's effects on economic development, and have largely asked and answered the wrong questions, we believe the prevailing view is unduly pessimistic and harsh' (Massey et al. 1998:272).

However, the issue was thrust into the foreground in mainstream development circles when the World Bank Global Development Finance Report 2003 drew attention to the massive growth in remittances (Ratha 2003). As the scale of global remittances, which dwarfed the funds provided by aid and foreign direct investment in developing countries, was realised, the development potential of such private sources of funds became a subject of extreme interest.

\footnotetext{
${ }^{8}$ MPI Data Hub http://www.migrationinformation.org/datahub/index.cfm
} 
In many quarters they seem to have become the 'new development mantra' (Kapur 2004) and come to be seen as 'an important and stable source of external development finance' (Ratha 2003). According to the World Bank, migrants' remittances sent to developing countries rose from $\$ 85$ billion in 2000 to an estimated $\$ 199$ billion in 2006 (World Bank 2006). In 2002, Africa received $\$ 12$ billion in remittances, 15 percent of the global total. Two thirds of this was sent to North Africa, in particular to Egypt and Morocco. In sub-Saharan Africa, recorded remittances are rising more slowly than other regions and are still considerably less than official development aid, but they still make a vital contribution to the balance of payments and, of course, to recipient households and communities (Sander and Maimbo 2003). ${ }^{9}$

Striking a more sceptical note, Kapur observed that the new enthusiasm for remittances is not simply the result of new research findings but also a reflection of changing ideologies and the failure of other development approaches. After half a century of development interventions there is still very limited progress. This is especially the case in Africa, which is frequently discussed in apocalyptic terms of worsening crisis, disaster and decline. Development as practiced over the last sixty years has not delivered the hoped for results. In other regions there is significant progress towards the Millennium Development Goals but across Africa the prospects of achieving many of them remain very slim to vanishing.

[A]s with the euphoria with private capital flows in the mid-1990s, the attractiveness of remittances is in part a reaction to previous failed development mantras. Development thinking has been as prone to fads and fashions as private capital flows are alleged to be. Remittances strike the right cognitive chords. They fit in with a communitarian, "third way approach" and exemplify the principle of self-help. People from poor countries can just migrate and send back money that not only helps their families, but their countries as well. Immigrants, rather than governments, then become the biggest provider of "foreign aid". The general feeling appears to be that this "private" foreign aid is much more likely to go to people who really need it. On the sending side it does not require a costly government bureaucracy, and on the receiving side far less of it is likely to be siphoned off into the pockets of corrupt government officials. It appears to be good for equity and for poverty and yet imposes few budgetary costs. What could be better? (Kapur 2004: 7)

\footnotetext{
${ }^{9}$ It is important to note that these recorded remittances grossly underestimate the total remittance flows to Africa as migrants use many informal channels to transfer money (World Bank 2006).
} 
Alongside this interest in remittances, there is also a growing recognition of the importance of transnational practices in shaping the relationship between migration and development (Nyberg-Sorensen et al. 2002; Vertovec and Cohen 1999). Migrants maintain links with the country of origin through a complex network of cultural, economic, social and political relations, which can now be sustained through new technologies (internet, mobile telephony) and cheaper travel (Mazzucato 2005). For example, rather than simply sending money, it is now possible for migrants to invest in businesses over which they can have some oversight from a distance using cheap telephony, texts (SMS), email, web-cameras and so forth.

This recognition of the ongoing transnational linkages between migrants (and their descendants) and their countries of origin has spurred a growing interest in the role of these diasporas in development. Until recently the concept of 'diaspora' was seen as the preserve of cultural studies and appeared rarely in development studies (or African studies) literature (Mohan and Zack-Williams 2002; Zack-Williams 1995). Today it is firmly established in the development lexicon and there is a rapidly expanding literature on the potential engagement of the diaspora in development processes (de Haas 2006a; Henry and Mohan 2003; Ionescu 2006; Mohan and Zack-Williams 2002; Nyberg-Sorensen et al. 2002). This is in stark contrast to the situation in 1995, when Zack-Williams lamented the spatial focus of development studies on 'developing' states and corresponding 'ostrich-like detachment from issues of race and diasporan concerns' (1995: 351). While the extent to which those coming from the perspective of diaspora studies and those from development studies are working with the same concept of 'diaspora' may be open to debate, the dialogue has started.

Another critical factor pushing migration to the top of the development policy agenda is the growing concern about irregular migration into the industrialised world. Undocumented migration from Africa into Europe through people smuggling, trafficking and other illegal routes is a major political priority in the EU. The pictures of young African men arriving on boats in the tourist destinations of the Mediterranean and Canary Islands give a popular impression of migration out of control, even though the numbers of people involved are relatively small. Such movements are seen to be driven by desperation and poverty, i.e. the failure of development, and create a huge pressure to find solutions which stops such desperate measures. (Baldwin-Edwards 2006)

This growing irregular international migration is represented as a threat to social cohesion, security and the nation state. The use of smugglers to co-ordinate illegal entry is often 
portrayed as feeding into organised criminal gangs, although there is evidence that the picture is much more complicated, with many of those involved being relatives and friends rather than criminal organisations. With the so-called 'war on terror' the presence of undocumented strangers is also presented as a major security threat (IISS 2004 cited in Lutterbeck 2006), especially when the migrants come from unstable (Islamic) states, such as Somalia and Sudan.

Of course, the other side of the story is the need for labour within the EU which cannot be met from its own population. While the politicians devise ever more stringent measures to stop illegal movement into Europe, there is every incentive for people to come and for businesses to employ them. Irregular migration from Africa to the US is inevitably much smaller given the costs involved. However, there appear to be many parallels between the discussions around how to deal with migration from Mexico to the US as from Africa to Europe (Castles 2006).

As a result of such factors the links between migration and development have become a topic of immense importance across the world and generated a huge range of initiatives. During 2006, the importance of topic within the United Nations was emphasised with the appointment of a Special Representative to the Secretary-General on International Migration and Development, the formation of the Global Migration Group (GMG) of multilateral agencies involved in migration-related activities at the beginning of the year and the organisation of UN High Level of International Migration and Development in September. The GMG includes major development actors such as UNDP and the World Bank; it aims to capitalise on the opportunities and respond to the challenges presented by international migration.

\section{DEVELOPMENT ACTORS AND MIGRATION}

Despite these shifts in recent academic and high level policy debates, many mainstream development actors, especially international development NGOs, have maintained at best an ambivalent, or more commonly a negative view of migration, if they consider the subject at all. International migration from developing countries to the industrialised states is uniformly presented as a problem - highlighting the brain drain and exploitation of migrants in Europe, the abandonment of families, issues of trafficking and people smuggling and so forth. It is rarely, if ever, presented as a potential solution, albeit not a straightforward one, which could 
be supported. Development practice still clings to its sedentary roots within governments, NGOs and many donors.

The attitudes of African governments towards migration can be clearly seen in the way in which they incorporate it into their development planning. In 2003, Sussex Centre for Migration Research conducted a review of the Poverty Reduction Strategy Papers (PRSPs) prepared by 48 states. It found that 27 made reference to migration and these were mostly 'in negative or pejorative terms' (cited in Ellis and Harris 2004: 9). Of the 22 African PRSPs included in the survey, only six had anything positive to say about migration: Cape Verde, Ethiopia, Mali, Niger, Rwanda and Senegal (Black 2004: 24-26).

In Nigeria, migration has hardly figured as a policy concern and until recently no connection was made between international migration and development. There has been much more focus on internal rural-urban migration, which was considered to cause social dislocation and create urban unemployment. In Nigeria's PRSP there is the warning that if internal migration continues, 'the rate of urban unemployment could become unmanageable. The implications for poverty — and crime, conflict, and the maintenance of democracy—are grave' (cited in de Haas 2006b: 14). The Kenyan government sees migration as one of the causes for the breakdown of the extended family and it traditional systems of social protection. (Black et al. 2004: 21). In Ethiopia, the PRSP suggests, perhaps unsurprisingly, that controlled migration, which occurs as part of the state policy of planned resettlement from lowlands to highlands can be beneficial; in contrast, spontaneous migration causes natural resource degradation (Black 2004: 24-26).

The negative rhetoric of 'mainstream' international development NGOs is equally striking. For example, sifting through the websites of Oxfam International, ActionAid, Save the Children UK, Christian Aid, and Concern Worldwide, the references to migration almost invariably cast it as the cause or symptom of multiple problems in developing regions, especially Africa. For example, it is portrayed as:

- Increasing labour demands on those left behind ${ }^{10}$

- A negative impact of the crisis in agricultural productions - alongside the production of illicit crops ${ }^{11}$

\footnotetext{
${ }^{10}$ http://oxfam.intellidirect.com/e/d.dll?m=235\&url=http://www.oxfam.org/en/files/pp030827_corn_dumping.pdf, http://www.christianaid.org.uk/wafrica/harvest.htm both accessed 9th May 2007

${ }^{11}$ http://www.oxfam.org/en/policy/briefingnotes/bn0604_coffee_groundsforchange accessed $9^{\text {th }}$ May 2007
} 
- A desperate measure to avoid poverty ${ }^{12}$

- Cause of spread of HIV/AIDS ${ }^{13}$

- Undermining traditional institutions ${ }^{14}$

- Undermining health services ${ }^{15}$

Others, such as Plan International, one of the largest international development NGOs in the world, make no mention of migration at all; this suggests that they see it as having little relevance to their work.

Oxfam GB appears to provide a counter-example in its positive statement on migration to the UK Parliament International Development Committee, but it only links it to Oxfam's work on asylum in the $\mathrm{UK}^{16}$. It has nothing to say about relationship of migration with development outcomes in the global south.

Of course this is by no means representative of development NGOs working across Africa but it illustrates the perspectives of some of the largest organisations that have greater access to current research and policy debates than most African NGOs. Moreover, they are often acting as conduits for donor funds through partnership agreements to national NGOs. As a result, they play a major role in shaping 'mainstream' development practice. It is hard to find any evidence of African development NGOs that depart significantly from this negative view of the relationship between migration and development.

Many donors appear to hold to the view that migration is a result of poverty, and investment in development can serve the purpose of reducing the levels of out-migration from rural areas to cities or from developing regions to industrialised states. For example, in Ethiopia, the African Development Banks has given loans and grants to a total of $\$ 86$ million to the Ethiopian government to 'control what it sees as a massive explosion in rural to urban migration' (Black et al. 2004: 15).

\footnotetext{
12 http://oxfam.intellidirect.com/e/d.dll?m=235\&url=http://www.oxfam.org/en/files/pp030827_corn_dumping.pdf, http://www.actionaid.org/main.aspx?PageID=187 both accessed $9^{\text {th }}$ May 2007

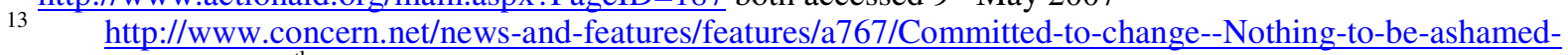
of.html accessed $9^{\text {th }}$ May 2007

${ }_{15} \underline{\mathrm{http}: / / \text { www.oxfam.org.uk/what_we_do/issues/livelihoods/landrights/downloads/hivsynth.rtf }}$ http://www.savethechildren.org.uk/scuk/jsp/resources/details.jsp?id=3977\&group=resources\&section=news\& $\underline{\mathrm{S}}$

ubsection=details accessed $9^{\text {th }}$ May 2007

16 http://www.oxfam.org.uk/what_we_do/issues/conflict_disasters/migration_development.htm
} 
The European Commission in its review The Global Approach to Migration One Year On: Towards a Comprehensive European Migration Policy (CEC 2006) makes its view of the link between migration and development quite explicit:

'Turning to the migration and development agenda, the prime challenge is to tackle the main push factors for migration: poverty and the lack of job opportunities. The EU must recognise that creating jobs in developing countries could significantly reduce migratory pressure from Africa. Migrants should be supported in contributing to the development of their countries of origin....

‘... Promoting investments in labour intensive sectors in regions with high outward migration will be an important priority' (CEC 2006: 5).

In contrast to such attitudes, the UK Department for International Development (DFID) has taken a lead in bringing migration as a positive factor into its development agenda. In March 2007 it published a policy paper Moving out of poverty - making migration work better for poor people which sets out its strategy for future work on migration and development. It appears to place migration in the centre of development processes, stating that

'DFID believes that actions to allow the movement of people deserve as much attention as the movement of capital, goods and services, to enable the benefits of globalisation to be sustained and shared equitably.' (DFID 2007: 37)

It highlights a range of policy priorities for DFID incorporating migration issues into its work to 'maximise the benefits and minimise the risk of migration for poor people and developing countries'. In summary, these include:

- managing migration at national level and planning for internal mobility;

- opportunities for legal migration including low-skilled migration where these meet the labour-market needs of receiving countries;

- facilitating the circulation of highly skilled migrants;

- migrants' access to their human rights and their legitimate entitlements under national law;

- low-cost and secure mechanisms for sending remittances and investing them in poor communities;

- support for positive diaspora activity; and 
- managing migration at regional and international levels. (DFID 2007: 3, also $37-40)$.

The DFID document illustrates the growing concern among donors to bring about the winwin-win scenario, where migration is good for the country of origin, the country of destination and the migrants themselves.

\section{Engaging Migrants as Development Actors}

With the upsurge of interest in migration and development, one of the most obvious shifts in development policy has been the new emphasis on engaging migrants and diasporas as actors in mainstream development processes. These have focused on a range of initiatives around four broad areas:

- Remittances - working with financial services industry to reduce the transaction costs for remittances and encourage migrants to send more funds through the formal banking system. Some have advocated the provision of tax breaks in industrialised states for migrants sending money to developing countries and some developing countries have considered how to tax remittances to raise funds for development. After highlighting the scale of remittances and the potential contribution of migrants to development, the World Bank has made some moves to moderate states' resultant enthusiasm for 'capturing remittances' by emphasising the private nature of these transactions (see for example, Ratha 2007: 7).

- Investments - while remittances are private flows targeted to families and friends, the governments of developing countries are increasingly attempting to encourage their diasporas to invest in their country of origin by building up businesses or the purchase of government bonds (Ketkar and Ratha 2007).

- Active engagement in development processes - in many areas diaspora groups with their origins in the same area establish hometown associations to channel resources to the 'hometown' for 'development activities'. These might range from sending funds to an existing initiatives (support for schools and clinics), to establishing new development projects designed, funded and implemented by the migrant association. 
- Knowledge transfer - there are various schemes to harness the skills and expertise of migrants to support development. For example, the UK-based diaspora organisation Africa Foundation for Development (AFFORD) has established a Diaspora Development Professionals Network with the aim of supporting Africans who are working in development organisations. They have also established a network, MAHDREIA, for people interested to invest in Africa with their time, money and skills. ${ }^{17}$

For example, both DFID and the Dutch Ministry of Foreign Affairs, which is responsible for development funding, are funding diaspora organisations involved in development. Ghana, which stands out in sub-Saharan Africa for its high level of remittances, has recently changed the law to allow dual nationality and voting rights; it is also considering introducing a special status for the African-American diaspora to enable them to buy property and invest in the country. Mainstream development NGOs have been much slower to pick up on the issues. Two of the major development NGOs in the Netherlands, Oxfam Netherlands (Novib) and Cordaid have made efforts to collaborate with diaspora organisations but these are the exception (Bakewell 2004; de Haas 2006a).

There have also been multilateral programmes to engage the diaspora in development initiatives (Ghosh 2000). The UNDP programme for the Transfer of Knowledge Through Expatriate Nationals (TOKTEN) established in 1976 was one of the earliest multilateral initiatives to encourage migrants to contribute their expertise for the benefit of their country of origin. TOKTEN aims to counter the effects of the brain drain by matching migrants with appropriate expertise for short-term consultancy assignments in their country of origin. For example, in Rwanda, TOKTEN operates under the strap line 'encouraging Rwandan diaspora professionals to serve their country. ${ }^{18}$ IOM took another approach with an attempt to encourage the permanent return of African migrants from industrialised states. From 19931998, it ran the Return and Reintegration of Qualified African Nationals programme (RQAN) funded mainly by the EU, which supported the return of 2,000 people but was found to be very expensive ${ }^{19}$. In 2001, a new initiative was launched with more moderate aims of encouraging migrants' engagement in development initiatives through temporary placements rather than permanent return. It describes Migration for Development in Africa (MIDA) as a

\footnotetext{
17 http://www.afford-uk.org/services/mahdreia/ accessed $9^{\text {th }}$ May 2007

18 http://www.toktenrwanda.org/index.php3 accessed $9^{\text {th }}$ May 2007

19 http://www.irinnews.org/Report.aspx?ReportId=24166 accessed $9^{\text {th }}$ May 2007
} 
'capacity-building programme, which helps to mobilize competencies acquired by African nationals abroad for the benefit of Africa's development. ${ }^{20}$

\section{The Flawed Virtuous Circle of Migration and Development}

Despite these initiatives on migration and development, the underlying model of sedentary development seems to remain intact. They are based on an assumption that poor people move because of inequality and (largely economic) opportunity and they would prefer to stay at home. Moreover, from the perspective of industrialised states, migration, while economically necessary, presents enormous social and political challenges; they are therefore anxious to find ways to bring migration from developing countries under control and preferably reduce it.

The link between migration and development is seen to offer a virtuous circle which is very attractive. Migration contributes to development through various mechanisms, generally relying on the migrant maintaining links with the country of origin and at some stage returning to it (Olesen 2002). As the economic conditions in the country or region of origin improve, this reduces inequality between countries and provides new opportunities for people at 'home'. As a result, there is less incentive for people to leave their country and the flow of migrants will slow down. Indeed, as the conditions improve further, the flow of migration may be reversed as old migrants return to their country of origin. (African Union 2006: 4)

While it may be realistic to expect that improved economic conditions will change the pattern of migration and may even reduce the net outflow of people in the long term (for instance, drawing on the experience of Ireland, Italy, and Portugal), many of the policy statements about migration suggest that investing in development is a means to reduce migration. They are phrased in terms that suggest sympathy for those who are forced to leave their homes on account of poverty to search for opportunity elsewhere. They use the technical language of migration management to ensure the legal movement of people under the control of states. For example, one of the oldest initiatives on migration and development is the French government's policy of co-development. When it started, an important element of this initiative was to provide funding for the reintegration of migrants who return to their country of origin (see Box). This explicit link between investment in development and the return of

\footnotetext{
${ }^{20}$ http://www.iom.int/jahia/page1306.html accessed 26th October 2006
} 
migrants to their country of origin has now been dropped but the implicit connection is still there.

Co-development $-1^{\text {st }}$ Co-development Newsletter produced by the French government

- Co-funding projects in country of origin by migrant associations (possibly $30 \%$ from association, $70 \%$ from government)

- Project funding for work carried out by highly skilled migrants in country of origin

- Economic reintegration assistance for migrants wanting to return to start businesses there. Source: http://www.diplomatie.gouv.fr/en/lMG/pdf/codevelopment newsletter no1-2.pdf

While none of the policy suggestions included in DFID's policy paper make any reference to the return of migrants, the virtuous circle of migration stimulating development and in due course the happy ending of migrants' eventual return to their 'homes' (which remain in developing countries) can be seen running through the document. For example, in the foreword, the Minister for Development, Hillary Benn writes:

Why do people choose to migrate? To take advantage of jobs elsewhere, to use their skills better, or simply because there are few opportunities to earn a living where they are. Whatever the reason, many migrants and their families benefit from the experience. The result is a vast increase in the money people send home: for example in Ghana recorded remittances are about the same as aid flows, around $\$ 1$ billion a year; governments are beginning to encourage their diaspora to invest; and people are returning home with new skills and a fresh outlook on life. (DFID 2007 emphasis added)

The trouble with this virtuous circle is that it assumes that all the actors involved have a common view of the 'good' ends to which the process leads them. It operates on the assumption that the normal and desirable state for human beings is to be sedentary. The fact that less than three percent of the world's population live outside their state of origin suggest that this might be the case. However, all the evidence suggests that as people get more opportunities to move they take them up in ever larger numbers. It is not the poorest of the poor who migrate, they cannot afford it, but it is those with lower-middle incomes. Mobility is a privilege of the relatively wealthy and only the poor (prisoners) are forced to stay in their place (Skeldon 1997a: 2). This is not to suggest that everyone would become a migrant given the chance, far from it. However, it is very likely that more people would move given the chance and once they have moved, is it safe to assume they will want to return? 


\section{RETHINKING DEVELOPMENT IN A MOBILE WORLD}

In practice, in developing countries, some of the initiatives on migration and development are concerned with delivering the same development projects by new means. For example, the IOM's Migration for Development in Africa (MIDA) Guinea Women's Project aims to encourage the development of women's micro-enterprise with training provided by members of the Guinean diaspora. However, this seems to engage diaspora members in a model of development which appears exactly the same as that which has been offered by the development 'professionals' for many years and found wanting. Looking at the box below, it is hard to see how this differs from the reports of many similar micro-enterprise initiatives run by development NGOs. In such a project, it is important to ask what is the added value brought by the diaspora involvement.

In order to make sense of the complex interaction between migration and development, it is necessary to go further than analysing how far migration affects development as it is currently conceived. The contribution of migrants to existing development practices may be valuable (to the extent that existing development practice is valuable), but it is based on the ideal that everyone should be able to stay at 'home' or go 'home'. It is impossible simply to bring migration into development (such as 'inserting migration into the Millennium Development Goals') without raising fundamental questions about the nature of development and how it is put into practice. These include asking about the conception of the good life in mainstream development goals; the appropriateness of models of development based on the nation state; and, the inherent paternalism of mainstream development practice. 


\section{Migration for Development in Africa (MIDA)}

IOM launched the MIDA Guinean Women's Project, financed by the US Government, to assist deprived women in the country through the dissemination of skills and experience of members of the Guinean diaspora. It provided technical and material support to 60 women beneficiaries for the development of micro-enterprises. In the selection process priority was given to poor women, who were engaged in small-scale activities to meet the needs of their families. None had previously received any micro-credits or training.

Members of the Guinean diaspora were recruited to provide the women with training in the creation and management of micro-enterprises. IOM started with the conviction that the Guinean diaspora included many highly qualified expatriates. Some of them have acquired the necessary knowledge and know-how for the creation and management of enterprises, which they can pass on to their fellow nationals in the home country, whose situation is becoming increasingly precarious.

Two women were selected from the Guinean diaspora in Senegal, and one man who had been part of the Guinean diaspora and had returned to Guinea and set up a development project consultancy. The three instructors worked hand-in-hand with instructors of Guinea's Rural Credit, acting as IOM's technical partner for the project. Through the preparatory activities conducted ahead of the training, IOM helped to strengthen the capacities of Rural Credit personnel, which has had a positive impact on all the institution's women customers.

The contents and execution of the training scheme were designed so that, by the end of their training, participants were fully familiar with the basic issues concerning the creation and management of micro-enterprises. Their personal experiences have been constantly incorporated into the learning process so that their acquired skills, which are rooted in scenarios based on their personal lives and the activities of their communities, may be directly applicable to the local situation and to their micro-enterprises.

The diaspora instructors, who had remained well acquainted with the realities of the home country, were able to adapt the knowledge they transmitted to the specific socio-economic conditions of Guinea, and to deliver the courses in the three main local languages (bearing in mind that most of the beneficiaries are either illiterate or semi-literate). At the end of their training, the women received a low-interest loan (IOM negotiated lower interest terms at a regressive rate of 2 per cent per month). The amount of credit allowed was decided on a case-by-case basis according to the type of the project undertaken by individual women. The sums allocated ranged from 300,000 GF (approximately USD 155) to 650,000 GF (approximately USD 332), with average loans amounting to 475,000 GF or USD 242.

Thanks to this financial assistance and with the new knowledge they have acquired, the women have been able to either start up or further develop profitable micro-enterprises. The main actvities created or improved included the sale of consumer products, dyeing, sewing, tapestry, small-scale catering, soap manufacture and weaving.

(IOM 2005: 46-47)

\section{Different conceptions of the good life}

The goals and objectives of mainstream development organisations can be characterised as being concerned with improving the quality of life of those who are living in appalling poverty. This necessarily entails having a conception of what constitutes an improved quality of life; how do we know this good life when we see it? 
The work of development organisations is framed by a (usually implicit) conception of the good life to which people will (or should) aspire. Over the last fifty years, development goals have evolved from an early focus on improvements in income, to a broader analysis of poverty, livelihoods and more recently notions of 'well-being'. This has been accompanied by a growing concern within development organisations to understand the perspectives of the people with whom they work; to move away from 'blueprint' planning and undertake 'bottom-up' development. Development rhetoric is awash with notions of "participation", "empowerment" and "ownership" of the development process, but these are related to a largely sedentary idea of development.

Most development initiatives are focused on geographical areas and aim to have an impact on the lives of people within the programme area - the nation, the region, the district, the city or the village. A 'successful' development programme will help to create the conditions in that area in which people are able and willing to live and flourish. They will improve the quality of life to such an extent that people feel do not feel the desire to move away. Therefore, in general, a reduction in out-migration is taken to be an indicator of development success. A development programme operating in a particular area will be seen as a failure if there is a continued exodus of population from the area. This is recognised by DFID's policy paper which states:

For development professionals, particularly those involved in rural development and urban planning, migration has been viewed as a failure of development, as people leave their communities despite programmes and projects to help them improve their lives in their home areas. (DFID 2007: 33)

When it comes to migration there still appears to be a gulf between the development organisations conception of the good life and that of many people with whom they work. While the former look to a future where people can achieve a better quality of life at 'home', the latter may see improved quality of life related to greater opportunities to travel and establish a new 'home' elsewhere. Such autonomy is an essential part of the notion of development as freedom put forward by Sen (1999) but it is not clear how it can be incorporated into the mainstream of development practice.

Part of the problem may be may be the longstanding concern of development initiatives to preserve people's ways of life as far as possible. This echoes the colonial interests in maintaining 'tradition' and reflects static, essentialised notions of tradition and culture, at 
least with respect to their place of residence (there is less concern about preserving other fundamental aspects of tradition such as family size). For example, it is easy to assume that subsistence farmers want to make their way in agriculture rather than have aspirations to become traders in the cities. Of course, many farmers may want maintain their rural livelihoods but is it reasonable to assume that they (and future generations) will always hope for the same rural existence, especially as their horizons expand with improved education, communication and transport links which expose them to (and prepare them for) the possibilities of life in the city or overseas (Peil and Sada 1984; Simon 1997)?

The life of a subsistence farmer is tough and may offer few chances for improvements over the generations. If anything the prospects are shrinking across Africa as it engages in the global economy and more people are likely to move off the land - and see it in their best interests to do so (Ellis 2003). Similarly, life in Asmara, for instance, may be hard and if you can take a chance to get to Italy and make your way picking tomatoes, life will be tough but you may see more chance of fulfilling your aspirations. For many of those subject to such development initiatives, these development activities may be trying to maintain a way of life which they would love the chance to abandon.

Not only do the goals of development programmes often fail to take account of people's changing aspirations, but the methods commonly used by development professionals to analyse poverty and livelihoods struggle to cope with mobility. For example, the sustainable livelihoods approach, which has adopted in various forms by many international development agencies, claims to counter assumptions about people's livelihoods based in particular places:

In the past rural people were essentially viewed as farmers, foresters or fisherfolk and urban people were generally considered to be wage labourers seeking employment or participants in the 'informal sector'. Development efforts sought to improve the services and opportunities available to these categories of people. The sustainable livelihoods approach, by contrast, seeks to develop an understanding of the factors that lie behind people's choice of livelihood strategy and then to reinforce the positive aspects (factors which promote choice and flexibility) and mitigate the constraints or negative influences. (DFID 1999: 2.5)

The approach requires an analysis of livelihoods that takes account of migration practices, income from remittances, and consider households spread across multiple locations. While it is clear that migration could be considered as strengthening the livelihoods of poor 
households and providing 'pathways out of poverty', this potential is blocked by the policy environment (Ellis 2003). Although the livelihoods approach could highlight such issues, in practice there is little encouragement for analysts to consider migration as a fundamental component of the way of life. Hence, for example, in the guidance sheets to the approach practitioners are encouraged to ask of livelihoods strategies:

How 'positive' are the choices that people are making? (e.g. would people migrate seasonally if there were income earning opportunities available closer to home or if they were not saddled with unpayable debt? ...) (DFID 1999: 2.5)

The guidance sheets also emphasise, quite correctly, that migration makes the analysis of livelihoods and poverty more complicated as one has to bring translocal and transnational relationships into the equation.

A failure to fully understand mobility and migration results in an insufficient understanding of what the poor do to make a living and how policy can help them to maximize the benefits of multi-locational livelihood strategies. (Deshingkar and Grimm 2005: 51 emphasis in original).

While academic critiques of livelihood approaches have highlighted the need to take account of mobility in their analysis - by paying more attention to networks for example (Kaag et al. 2004: 13) - on the evidence of their limited engagement with issues of international migration, there is little sign yet that development practitioners have risen to this challenge.

\section{National models of development}

Apart from the sedentary assumptions underlying development goals and practices, the concept of development is spatially bound by its focus on 'developing' or 'underdeveloped' states (Zack-Williams 1995). Throughout the development industry, the nation state is the primary unit of analysis for the assessment of levels of development. The broad concern of most development actors is to see the situation of people living in particular territories improve. If those people move outside the development sphere, say to Europe, to a large extent they are no longer interesting to development actors, except in as far as they maintain their links with people who remain in place.

The fact that the individuals who migrate may increase their income many times over, be able to send their children to school, have access to good healthcare and the other benefits of 
Western life (alongside the many costs), counts for little in development terms. As Rimmer has put it:

No matter how remunerative migration might be, it is likely to be thought an unsatisfactory answer to the question of how Africa is to be developed. Individuals and their kin become better-off, but their places of origin remain backward or underdeveloped. But this perception signifies only in the context of a world we divide into nations or states. In this context Sudan counts for more than the Sudanese, Nigeria for more than the Nigerians, Ethiopia for more than the Ethiopians. (Rimmer 2003: 488)

It is obvious why both donors and developing states must be drawn into models of development bound by national borders. It is unsurprising that national NGOs in developing countries focus on their own country. It is less clear why international development NGOs, which purport to care about global inequality and injustice, uniformly follow the same path.

If we look at development within nation states, assuming people have the resources and the freedom to move, we expect to find changing patterns of residence in response to changes in the economy, technology, the environment, culture and many other factors. As economies have developed there has been a general shift from rural areas to the cities and the proportion of the population engaged in agricultural production has gone down dramatically. Looking at the US, the overall population has doubled since the 1930s, but huge areas have seen high levels of out-migration and population decline in that period. For example, the population of a contiguous area of Kansas and South Dakota larger than Ghana fell by $28 \%$ between 1930 and 1990 (Pritchett 2004: 36).

If such large areas in the US cannot hold their populations, despite the wealth available in the nation to support the rural infrastructure and rural livelihoods, this raises the question of whether there are similar areas across Africa which might be areas destined for such decline into 'ghost countries' (Pritchett 2004). It is important to stress, this is not saying the people are in decline but given the option in the long term, they may vote for the country and a lifestyle with their feet to find 'better' lives elsewhere. Development action to sustain some rural areas or even whole countries may be attempting to create artificial incentives to keep people in their place. 'States, we suppose, have a right to be developed, to become like our own. International aid has unavailingly sought for half a century to sustain this right' (Rimmer 2003: 488). In some cases, perhaps we have to ask if investing such aid is wasteful 
when migration may be a more attractive and sustainable option for those people who have the opportunity to take it.

Precisely because all current policy discussions focus only on Zambia [for instance] - the nation-state -- and not on Zambians the people. International organizations and international negotiations and international forums tend to be exactly that - international where the actors and agents all represent nation-states and their interests. There are structured organizations and institutions for bringing about reductions in the barriers to the movement of goods, for the movement of finance. There are organizations to bring about national development. But almost certainly the easiest way to improve the living standards of a Zambian is not to improve living standards in Zambia but to allow the person the choice to move out of Zambia. (Pritchett 2004: 50)

Pritchett and Rimmer (both economists) present similar radical conclusions which raise profound challenges for the mainstream development industry and its relationship with international migration.

[T]o insist on the interests of nation-states to control their borders over all other considerations-including the well-being of human beings, who through no action or fault of their own are trapped in economically non-viable regions-is not a normatively attractive view (Pritchett 2004: 50).

An exacting test of how serious we are about reducing inequality in the world is whether we are prepared to allow migration into the advanced economies of people from Africa and other poor areas. By this test, few of the advocates of international aid are really serious (Rimmer 2003).

\section{Paternalistic paradigm}

The prevailing paternalism of development discourse is another major obstacle to development actors accepting the possibility that migration may be an important strategy for many people in poor countries to improve their quality of life. In general, they work with a strong sense that migration, particularly international migration, is a 'bad' thing and people should want to stay at 'home'. Development organisations are still largely operating with a paradigm that considers migration only as one of the development problems to be addressed. 
As already noted above, this means that the development organisations often assume sedentary goals which may fail to match the interests of their 'target groups'. By failing to understand why people migrate and viewing this migration as a problem, there is a tendency to assume away the agency of migrants, especially poor migrants, and cast them as victims who need assistance.

It is easy to portray the migrants caught up in this global labour market as powerless in the face of a vicious system. Indeed many of them may be. Amin, writing from a structuralist position, argues that the migrant 'rationalises the objective needs of his situation' so the necessity to migrate becomes an ideal, always underpinned by an economic rationale. $\mathrm{He}$ is then able to write off individual motivations as "nothing but rationalisations of behaviour within the system' (Amin 1995: 92-99). However, this does not explain why some move and while others remain at home; nor does it make sense of why people still migrate in the face of large obstacles and reasonable opportunities that would enable them to stay at home.

This is not to deny that many of those who migrate across borders start their journeys as reluctant migrants, who would prefer to stay at home. Many are exploited, cheated and abused along the way. However, for many despite the hardships on the road, having moved they look forward to a new life in a new country. Migration can be a rite of passage for the young. It may not be a comfortable process, it may be dangerous but it will remain a very important option for people who are looking to improve their lives and move out of poverty. Development agencies are quite rightly concerned to fight against the abuse of rights and exploitation, but they struggle to understand and respect people's decisions to take such risks. They tend to focus on international migration as the problem rather than looking at the abusive institutional framework within which it has to occur. People want to move, but for many often the only means to do so is through irregular channels which are often exploitative.

The discourse can become very moralistic. There is an underlying sense that African migrants must be desperate to abandon their families and take the dangerous journey to reach Europe as a last resort. Any idea that they may have other options and choose this route is unacceptable. The world of migrants becomes divided into the morally acceptable victims, who have no choices and need protection, and the morally irresponsible, who choose to take risks or worse make money from organising people's journeys and can therefore be criminalised. 
The language of both development studies and migration studies has been replete with examples of emotive and moralising terms about migrants over a long period. For example, it is still commonplace to complaints of their remittances being used for conspicuous or ostentatious consumption in the home areas, such as purchasing televisions or cars (Thouez 2005: 43). Apart from the large volume of research over many years challenging the 'myth' of conspicuous consumption (for example Adams 2006; Appleyard 1989), the term comes loaded with moral connotations of extravagance and recklessness which seem to be easier to apply to migrants from developing countries than Europeans loaded up with electronic goods on their return from Japan. Terms such as brain drain and brain waste both suggest some failure of people either to contribute as they should to their country of origin or to make the best of themselves. The current interest in migrant's engagement in development is overlaid with an expectation that migrants should want to maintain their links with the country of origin and, moreover, want to contribute to its development. Of course, as much recent work has shown migration is often part of a household strategy and many, if not most, migrants retain multiple obligations to their families and wider community. The point here is not to deny this reality, which has been empirically verified, but to object to the moralistic overtones of the assumption that migrant Africans should provide support not only to their kin but to the broader 'nation' for development. The idea of a migrant from Africa moving to a European state, changing citizenship and cutting links with their place of origin, without any particular interest in supporting its development, remains an uncomfortable one. However, there is no such discomfort with someone moving from Europe, say, in search of a new life in North America.

The discourse of migration and development in Africa is in danger of operating with an essentialised notion of 'belonging' to a particular place that even carries over generations through the diaspora. Of course, today it is becoming easier to sustain and develop transnational identities and networks that constitute important elements of many people's livelihoods and also make a vital contribution to development. The point here is to ask whether it is reasonable to assume that all people share such an interest and to imbue it with a sense of moral superiority.

\section{CONCLUSION}

In this paper, I have suggested that the rediscovery of the relationship between migration and development raises major questions for the nature of the concept of development found 
within the mainstream development industry. The negative view of migration is changing and the hunt is on for the win-win-win scenario where migration is good for countries of origin, countries of destination and migrants themselves. The challenge which is being widely presented is how to identify the conditions under which this triple win can be achieved. However, the deeper challenge, which is often neglected, is to agree on the nature of the 'good' for the different actors involved.

While migration and development have risen up the agenda, mainstream development agencies remain ambivalent about how they should bring migration into their work, or if they should do so at all. I have argued that this is a reflection of the sedentary nature of their concept of 'development' in Africa, which can be traced back to its roots in colonial practice. Although in many areas of development practice it may be possible to ignore the colonial inheritance - at least enough to provide cloak of respectability to allow the industry to function - the current emphasis on the migration and development makes such subterfuge unsustainable. The internal contradictions in a concept of development that says that migration can support development, but it is better if people stay at home become too blatant.

For international development organisations, mostly based in industrialised states, casting migration as a problem conveniently fits with a model of development that keeps poor people 'out there'. This remains acceptable in the wealthy constituencies of international development organisations. However, as Skeldon observed a decade ago, '[p]olicies that accept the wider mobility of the population are likely to accord with policies that will enhance the well-being of greater numbers of people' (Skeldon 1997b). It will be a brave chief executive of a European development NGO who suggests that facilitating higher levels of migration from developing countries into Europe may be a more effective way of reducing poverty than the launching of another development programme in Africa.

If we are to move away from paternalistic notions of development which assume that people want to stay in their place, we may do better to consider the broader processes of social transformations which are not bound to particular 'developing' regions of the world. If we assume that migration is a global phenomenon, shared by all humanity, our task is then to understand the complex relationship between migration and social transformations. We can then ask how mobility affects changes for better and worse in any society, rather than discussing it as an exceptional problem for Africa (Roe 1995). This might encourage us to 
avoid the assumption that mobility is normal for the wealthy, international elite, but a symptom of failure among the poor.

\section{REFERENCES}

Achanfuo-Yeboah, D. 1993. 'Grounding a Theory of African Migration in Recent Data on Ghana'. International Sociology 8: 215-226.

Adams, R.H. 2006. 'International remittances and the household: Analysis and review of global evidence'. Journal of African Economies 15: 396-425.

African Union 2006. 'Draft African Common Position on Migration and Development'. Addis Ababa: African Union.

Amin, S. 1974. 'Modern Migrations in Western Africa - studies presented and discussed at the 11th International African Seminar, Dakar, April 1972'. Oxford: Oxford University Press.

Amin, S. 1995. 'Migrations in Contemporary Africa: a retrospective view' in Baker, J. and Aina, T.A. (eds.) The Migration Experience in Africa. Uppsala: Nordika Afrikainstitutet.

Appleyard, R.T. 1989. 'Migration and Development: Myths and Reality'. International Migration Review 23: 486-499.

Bakewell, O. 2004. 'Migration as a Development Strategy: a challenge to development NGOs' Informed: NGO Funding and Policy Bulletin. Oxford: International NGO Training and Research Centre (INTRAC).

Baldwin-Edwards, M. 2006. "Between a rock \& a hard place': North Africa as a region of emigration, immigration \& transit migration'. Review of African Political Economy 33: $311-324$.

Black, R. 2004. 'Migration and Pro-Poor Policy in Africa'. Sussex: Development Research Centre on Migration, Globalisation and Poverty, University of Sussex.

Black, R., Hilker, L.M. and Pooley, C. 2004. 'Migration and Pro-Poor Policy in East Africa'. Sussex: Development Research Centre on Migration, Globalisation and Poverty, University of Sussex.

Brigg, M. 2002. 'Post-development, Foucault and the colonisation metaphor'. Third World Quarterly 23: 421 - 436.

Castles, S. 2006. 'Back to the Future? Can Europe meet its Labour Needs through Temporary Migration?' IMI Working Paper. Oxford: International Migration Institute. 
CEC 2006. 'The Global Approach to Migration One Year On: Towards a Comprehensive European Migration Policy'. Brussels: Commission of the European Community.

Cohen, J.M. 1987. Integrated rural development :the Ethiopian experience and the debate. Uppsala, Sweden: Nordiska Afrikainstitutet.

Colson, E. 1971. The social consequences of resettlement : the impact of the Kariba resettlement upon the Gwembe Tonga. Manchester: Manchester University Press.

Cowen, M. and Shenton, R. 1995. 'The Invention of Development' in Crush, J. (ed.) Power of Development. London: Routledge.

Daveri, F. and Faini, R. 1995. 'Risk and Migration'. Oxford: Centro Studi Luca d'Agliano and QEH Oxford.

de Haan, A. 1999. 'Livelihoods and poverty: The role of migration - A critical review of the migration literature'. Journal Of Development Studies 36: 1-47.

de Haas, H. 2005. 'International migration, remittances and development: Myths and facts'. Third World Quarterly 26: 1269-1284.

de Haas, H. 2006a. 'Engaging Diasporas: How governments and development agencies can support diaspora involvement in the development of origin countries'. The Hague: Oxfam Novib.

de Haas, H. 2006b. 'International migration and national development: Viewpoints and policy initiatives in countries of origin - The case of Nigeria' Working papers Migration and Development Series. Nijmegen and the Hague: Radboud University, Nijmegen and Directorate General for International Cooperation (DGIS), Ministry of Foreign Affairs, The Netherlands.

De Jong, G.F. and Gardner, R.W. 1981. 'Migration Decision Making: Multidisciplinary Approaches to Microlevel Studies in Developed and Developing Countries' Pergamon Policy Studies on International Development. NY: Pergamon Press.

Deshingkar, P. and Grimm, S. 2005. 'Internal Migration and Development: A Global Perspective' IOM Migration Research Series. Geneva: International Organisation for Migration.

DFID 1999. 'Sustainable Livelihoods Guidance Sheets'. London: Department for International Development.

DFID 2007. 'Moving out of poverty - making migration work better for poor people'. London: Department for International Development.

Ellis, F. 2003. 'A Livelihoods Approach to Migration and Poverty Reduction'. London: Department for International Development. 
Ellis, F. and Harris, N. 2004. 'New Thinking about Urban and Rural Development' DFID Sustainable Development Retreat. University of Surrey, Guildford.

Escobar, A. 1995a. Encountering development: the making and unmaking of the Third World. Princeton: Princeton University Press.

Escobar, A. 1995b. 'Imagining a Post-Development Era' in Crush, J. (ed.) Power of Development. London: Routledge.

Ferguson, J. 1999. Expectations of Modernity: Myths and Meaning of Urban Life on the Zambian Copperbelt. Berkeley: University of California Press.

Ghosh, B. 2000. 'Return Migration: Reshaping Policy Approaches' in Ghosh, B. (ed.) Return migration: journey of hope or despair? Geneva: International Organization for Migration, United Nations.

Harris, J.R. and Todaro, M.R. 1970. 'Migration Employment and Development: a two sector analysis'. American Economic Review 60: 126-142.

Harriss, J. 2005. 'Great Promise, Hubris and Recovery: A Participant's History of Development Studies' in Kothari, U. (ed.) A Radical History of Development Studies: Individuals, Institutions and Ideologies. London: Zed Books.

Henderson, L.W. 1978. Angola: Five Centuries of Conflict. Ithaca and London: Cornell University Press.

Henry, L. and Mohan, G. 2003. 'Making homes: the Ghanaian diaspora, institutions and development'. Journal of International Development 15: 611-622.

IOM 2005. World Migration Report 2005: Costs and Benefits of Migration. Geneva: International Organisation for Migration.

Ionescu, D. 2006. 'Engaging Diasporas as Development Partners for Home and Destination Countries: Challenges for Policymakers' Migration Research Series. Geneva: International Organisation for Migration.

Kaag, M.M.A., Bruijn, M.E.d., Dijk, J.W.M.v., Haan, L.J.d., Berkel, R.v., Brons, J., Nooteboom, G. and Zoomers, A. 2004. 'Ways forward in livelihood research' in Kalb, D., Pansters, W. and Siebers, H. (eds.) Globalization and Development. Themes and concepts in current research. Dordrecht/Boston/London: Kluwer.

Kapur, D. 2004. 'Remittances: The New Development Mantra?' G-24 Discussion Paper Series. New York: United Nations Conference on Trade and Development.

Katseli, L.T., Lucas, R.E.B. and Xenogiani, T. 2006. 'Effects of Migration on Sending Countries: What do we know?' Paris: OECD. 
Keely, C.B. and Tran, B.N. 1989. 'Remittances from Labor Migration: Evaluations, Performance and Implications'. International Migration Review 23: 500-525.

Ketkar, S.L. and Ratha, D. 2007. 'Development Finance via Diaspora Bonds: Track Record and Potential' Migration and Development Conference. Washington DC: World Bank.

Kothari, U. 2005a. 'From Colonial Administration to Development Studies: a post-colonial critique of the history of development studies' in Kothari, U. (ed.) A Radical History of Development Studies: Individuals, Institutions and Ideologies. London: Zed Boooks.

Kothari, U. 2005b. 'A Radical History of Development Studies: Individuals, Institutions and Ideologies'. London: Zed Books.

Lipton, M. 1980. 'Migration from Rural Areas of Poor Countries: the impact on rural productivity and income distribution'. World Development 8: 1-24.

Lutterbeck, D. 2006. 'Policing Migration in the Mediterranean'. Mediterranean Politics 11: $59-82$.

Mabogunje, A.L. 1970. 'Systems Approach to a Theory of Rural-Urban Migration'. Geographical Analysis 2: 1-18.

Martin, P.L. and Taylor, J.E. 1996. 'The Anatomy of a Migration Hump' in Taylor, J.E. (ed.) Development Strategy, Employment, and Migration: Insights from models. Paris: Organisation for Economic Cooperation and Developent, Development Centre.

Massey, D.S., Arango, J., Hugo, G., Kouaouci, A., Pellegrino, A. and Taylor, J.E. 1998. Worlds in motion : understanding international migration at the end of the millennium. Oxford: Clarendon Press.

Mazzucato, V. 2005. 'Ghanaian migrants' double engagement: a transnational view of development and integration policies' Global Migration Perspectives. Geneva: Policy Analysis and Research Programme of the Global Commission on International Migration.

McKeown, A. 2004. 'Global Migration 1846-1940'. Journal of World History 15: 155-189.

Mercer, C., Mohan, G. and Power, M. 2003. 'Towards a critical political geography of African development'. Geoforum 34: 419-436.

Mohan, G. and Zack-Williams, A.B. 2002. 'Globalisation from Below: Conceptualising the Role of the African Diasporas in Africa's Development'. Review of African Political Economy 29: 211-236.

Moore, H.L. 1990. 'Johan Pottier - Migrants No More: Settlement and Survival in Mambwe Villages, Zambia'. Journal of Southern African Studies 16: 591-594.

Moore, H.L. and Vaughan, M. 1994. Cutting down trees : gender, nutrition, and agricultural change in the Northern Province of Zambia, 1890-1990. London: James Currey. 
Nyberg-Sorensen, N., Van Hear, N. and Engberg-Pedersen, P. 2002. 'The MigrationDevelopment Nexus: Evidence and Policy Options State of the Art Review'. International Migration 40: 3-48.

Olesen, H. 2002. 'Migration, Return, and Development: An Institutional Perspective'. International Migration 40: 125-150.

Peil, M. and Sada, P.O. 1984. African Urban Society. Chichester: John Wiley and Sons.

Pottier, J. 1988. Migrants No More: settlements and survival in Mambwe villages, Zambia: Manchester University Press.

Potts, D. 1997. 'Urban lives: Adopting new strategies and adapting rural links' in Rakodi, C.

(ed.) The Urban Challenge in Africa: Growth and Management of its Large Cities. Tokyo: United Nations University Press.

Pritchett, L. 2004. 'Boom Towns and Ghost Countries: Geography, Agglomeration, and Population Mobility' Working Paper Number 36. Washington D.C.: Center for Global Development.

Rakodi, C. 1997a. 'Conclusion' in Rakodi, C. (ed.) The Urban Challenge in Africa: Growth and Management of its Large Cities. Tokyo: United Nations University Press.

Rakodi, C. 1997b. 'Global forces, urban change, and urban management in Africa' in Rakodi,

C. (ed.) The Urban Challenge in Africa: Growth and Management of its Large Cities. Tokyo: United Nations University Press.

Rakodi, C. 1997c. 'The Urban Challenge in Africa: Growth and Management of its Large Cities'. Tokyo: United Nations University Press.

Ratha, D. 2003. 'Workers' Remittances: An Important and Stable Source of External Development Finance' Global Development Finance 2003. Washington DC: World Bank. Ratha, D. 2007. 'Leveraging Remittances for Development' MPI Policy Brief. Washington DC: Migration Policy Institute.

Ratha, D. and Shaw, W. 2007. 'South-South Migration and Remittances' World Bank Working Paper. Washington D.C.: Development Prospects Group, World Bank.

Rhoda, R. 1983. 'Rural Development and Urban Migration: Can We Keep Them down on the Farm?' International Migration Review 17: 34-64.

Richards, A.I. 1939. Land, labour and diet in Northern Rhodesia : an economic study of the Bemba tribe. London: Published for the International Institute of African Languages and Cultures by the Oxford University Press.

Rimmer, D. 2003. 'Learning about economic development from Africa'. African Affairs 102: 469-491. 
Roe, E.M. 1995. 'Except-Africa: Postscript to a special section on development narratives'. World Development 23: 1065-1069.

Rosenzweig, R. and Stark, O. 1989. 'Consumption Smoothing, Migration and Marriage: evidence from rural India'. Journal of Political Economy 97: 905-926.

Sahley, C. and Pratt, B. 2003. NGO responses to urban poverty : service providers or partners in planning? Oxford: INTRAC.

Sander, C. and Maimbo, S.M. 2003. 'Migrant Labor Remittances in Africa: Reducing Obstacles to Developmental Contributions' Africa Region Working Paper Series. Washington DC: World Bank.

Schuurman, F.J. 2000. 'Paradigms lost, paradigms regained? Development studies in the twenty-first century'. Third World Quarterly 21: 7 - 20.

Sen, A.K. 1999. Development as freedom. Oxford: Oxford University Press.

Simon, D. 1997. 'Urbanization, globalization, and economic crisis in Africa' in Rakodi, C. (ed.) The Urban Challenge in Africa: Growth and Management of its Large Cities. Tokyo: United Nations University Press.

Simon, D. 2006. 'Separated by common ground? Bringing (post)development and (post)colonialism together'. Geographical Journal 172: 10-21.

Skeldon, R. 1997a. Migration and Development: a global perspective. London: Longman.

Skeldon, R. 1997b. 'Rural-to-Urban Migration and Its Implications for Poverty Alleviation'. Asia-Pacific Population Journal 12: 3-16.

Stark, O. 1984. 'Rural to Urban Migration in LDCs: a relative deprivation approach'. Economic Development and Cultural Change 32: 475-486.

Stark, O. and Bloom, D.E. 1985. 'The New Economics of Labor Migration'. American Economic Review 75: 173-178.

Taylor, E.J. 1999. 'The New Economics of Labour Migration and the Role of Remittances in the Migration Process' 37: 63-88.

Thouez, C. 2005. 'The Impact of Remittances on Development' in UNFPA (ed.) International Migration and the Millennium Development Goals: Selected Papers of the UNFPA Expert Group Meeting, Marrakech, Morocco 11-12 May 2005. New York: United Nations Population Fund.

UN 2001. 'Road map towards the implementation of the United Nations Millennium Declaration - Report of the Secretary General'. New York: United Nations General Assembly. 
UN 2005. 'Trends in Total Migrant Stock: the 2005 Revision'. New York: United Nations Department of Economic and Social Affairs.

UNFPA 2005. International Migration and the Millennium Development Goals: Selected Papers of the UNFPA Expert Group Meeting, Marrakech, Morocco 11-12 May 2005. New York: United Nations Population Fund.

Van Velsen, J. 1960. 'Labour Migration as Positive Factor in the Continuity of Tonga Tribal Society'. Economic Development and Cultural Change 8: 265-278.

Vertovec, S. and Cohen, R. 1999. Migration, diasporas, and transnationalism. Cheltenham: Elgar.

Watson, W. 1958. Tribal Cohesion in a Money Economy: a study of the Mambwe people of Zambia: Manchester University Press.

Watts, M. 1995. '"A New Deal in Emotions" Theory and practice and the crisis of development' in Crush, J. (ed.) Power of Development. London: Routledge.

White, S. and Pettit, J. 2004. 'Participatory Approaches and the Measurement of Human Well-Being'. Bath: ESRC Research Group on Wellbeing in Developing Countries, University of Bath.

World Bank 2006. 'Remittance Trends 2006' Migration and Development Brief 2. Washington DC: Development Prospects Group, Migration and Remittances Team, World Bank.

Zack-Williams, A. 1995. 'Development and diaspora: separate concerns?' Review of African Political Economy 22: 349 - 358. 